\title{
The Concept and Process of Innovation Leading Based on the longitudinal case study of Haier (1984-2019)
}

\author{
Kan Yuyue ${ }^{1, a}$, Liu Haibing 2,b \\ ${ }^{1}$ School of Economic and Management, Lanzhou jiaotong University, Lanzhou \\ ${ }^{2}$ School of Management, Zhejiang University, Hangzhou
}

\begin{abstract}
Based on the exploratory case study method, this paper attempts to construct a theoretical framework of Innovation Leading from two aspects of concept and process. Based on this research framework, the article makes a longitudinal case study of the Haier Group's washing machine industry line, which is representative in terms of Innovation Leading the improvement of Core Competence, from 1994 to 2019. The study found: (1) From four dimensions of Value, Attitude, Effect and Driving (VAED), the concept of Innovation Leading is defined exploratory. (2) This paper theoretically discusses the process of Innovation Leading, namely ISAC model, including Innovation Intention, Innovation Strategy, Innovation Action and Core Competence. User demands are the trigger of Innovation Intention, which is the "navigator" and "brain". The Innovation Strategy is an innovation plan about technology and complementary assets led by Innovation Intention. Innovation Action is the carrier of Innovation Leading, including technological innovation and complementary asset innovation. Core Competence is the goal of innovation, and it is an organic unity of technological competence, market competence, organizational competence and cultural competence.
\end{abstract}

\section{Introduction}

"Innovation is the first driving force to lead development" is a major theoretical innovation achievement written in the report of the 19th National Congress of the Communist Party of China and the newly revised Party Constitution. Innovation is becoming a strong driving force for China's development ${ }^{[1]}$. So, how to recognize Innovation Leading and what is the realization process of Innovation Leading is a theoretical problem to be solved urgently.

\section{Theoretical background}

\subsection{The Concept of Innovation as An Idea}

Schumpeter first proposed the concept of "Innovation" in 1934, believing that Innovation is a "new combination" of production factors and production conditions. In Schumpeter's innovation theory, Innovation is regarded as an idea that drives economic development.

\subsection{The Concept of Innovation as An Element}

Taking innovation as an element means that innovation is relatively independent from the five elements of "planning, organization, command, coordination and control". Its connotation, structure and mechanism are gradually filled and enriched, and the main research areas covered by innovation include technology innovation [2], organizational innovation, cultural innovation [3], and cooperative innovation, Total Innovation Management ${ }^{[4]}$.

\subsection{The Concept of Innovation as a Methodology}

First, based on the technical distance, radical innovation ${ }^{[5]}$ and disruptive innovation ${ }^{[6]}$, Breakthrough innovation [7], major innovation [8], discontinuous innovation (discontinuous innovation) and other theories have emerged successively. Second, with the boundary of innovation as the standard, there has been a discussion on closed innovation and open innovation. 


\subsection{The concept of Innovation as Value Orientation}

The most influential and representative ones are inclusive innovation and responsible innovation.

\section{Research methods and data sources}

\subsection{Basis for Case Selection}

The purpose of this paper is to construct a theoretical framework of Innovation Leading through three aspects of concept, mechanism and structure. Selecting typical cases and extreme cases is a "common practice" in the study of such problems [9]. Typical case and extreme case is embedded in the research questions in this article, and case has the following characteristics: (1)Innovation Leading plays an important role in the long-term development of company.(2) Innovation Leading improves Core Competence.(3) Company is in a leading position in the industry.(4) Long-term and in-depth follow-up of company can ensure the smooth development of research.

\subsection{Sources, Collection Methods and Research Procedures of Case Data}

- Fieldwork. Fieldwork is the basic method of modern anthropology, but it has attracted more and more attention from many disciplines. Since the 1990s, the innovation management research team of Zhejiang University has been going to Haier Group to carry out field investigation for one month every summer vacation.

- Second-hand materials. The second-hand information was also consulted during the research process to provide some objective data for the research.

\section{Case introduction}

Since its development in 1984, Haier Group has evolved from a past home appliance brand giant to an Internet of Things(IoT) ecological brand that leads the development of the home appliance industry. Its products cover home appliances, communications, IT digital products, home furnishing, logistics, finance, real estate, biopharmaceuticals. The home appliance industry is still the core subgroup of the Company's product cluster. After the acquisition of GE Home Appliances Division, Sanyo, Fisher Paykel of New Zealand, and Candy in Italy, product innovation in refrigerator, washing machine, air conditioner, and water heater have further integrated global leading resources, gaining a strong competitive advantage in the industry. The specific cases are shown in Table 1 below.

TABLE I.

HAIER WASHING MACHINE PRODUCT DEVELOPMENT STAGE AND CASE EVIDENCE

\begin{tabular}{|c|c|c|c|c|}
\hline $\begin{array}{l}\text { Divisio } \\
\text { n basis }\end{array}$ & Innovation model & & & \\
\hline $\begin{array}{l}\text { Belongi } \\
\text { ng field }\end{array}$ & Second innovation & $\begin{array}{l}\text { Independent } \\
\text { innovation }\end{array}$ & Open innovation & Total Innovation \\
\hline $\begin{array}{l}\text { Core } \\
\text { charact } \\
\text { eristics }\end{array}$ & $\begin{array}{l}\quad \text { Technology } \\
\text { Introduction, Digestion } \\
\text { and Absorption }\end{array}$ & $\begin{array}{l}\quad \text { Independent } \\
\text { Innovation after } \\
\text { Digestion and } \\
\text { Absorption }\end{array}$ & $\begin{array}{l}\text { Integration of } \\
\text { external partners }\end{array}$ & $\begin{array}{l}\text { All staff, all time and } \\
\text { space, all elements innovation }\end{array}$ \\
\hline $\begin{array}{l}\text { Div } \\
\text { ision } \\
\text { stage }\end{array}$ & $1995-2000$ & $2000-2004$ & 2004-2009 & 2009-today \\
\hline $\begin{array}{l}\text { Cas } \\
\text { evidenc } \\
\text { e }\end{array}$ & $\begin{array}{l}\text { Before Haier } \\
\text { merged it, the washing } \\
\text { machine of Hongxing } \\
\text { Electric Appliance } \\
\text { Factory cooperated } \\
\text { with Sharp of Japan. } \\
\text { After the merger, the } \\
\text { cooperation gradually } \\
\text { became less close, and } \\
\text { innovation based on } \\
\text { mainly digesting and } \\
\text { absorbing the previous } \\
\text { technology. }\end{array}$ & \begin{tabular}{lr}
\multicolumn{2}{c}{ A double-powered } \\
washing machine was \\
invented \\
Americans & inventing \\
agitated & washing \\
machines, European \\
drum-type washing \\
machines and Sanyo's \\
pulsator-typer fully \\
automatic \\
machines.
\end{tabular} & \begin{tabular}{lr}
\multicolumn{1}{c}{ In cooperation } \\
with a $r$ water \\
treatment & enterprise \\
in Japan, a & washing \\
machine & without \\
washing & powder" \\
was developed and \\
designed r using \\
electrolyzed & water \\
technology.
\end{tabular} & $\begin{array}{l}\text { In October 2009, Haier } \\
\text { Open Partnership Ecosystem } \\
\text { (HOPE) was established. It } \\
\text { was originally an open } \\
\text { innovation team established } \\
\text { by Haier based on the concept } \\
\text { of "the world is my R \& D } \\
\text { department", and cooperates } \\
\text { with global R \& D center } \\
\text { innovation resources to } \\
\text { provide innovative services } \\
\text { for Haier's various industries. }\end{array}$ \\
\hline
\end{tabular}




\section{Case discussion}

\subsection{The Concept of Innovation Leading (VAED)}

- Value. The value orientation of Innovation Leading is beyond the satisfaction of the company's own interests and values, and is committed to the dual balance of the company's own interests and the promotion of social interests. It pays more attention to achieving its own interests in the process of promoting social progress.

- Attitude. In the paradigm of Innovation Leading, issues such as "whether to innovate" and "what kind of innovation to choose" have broken through the boundary of discussing innovation within the company. The company places more emphasis on the positive impact of innovation on industry, society, nation and country, and regards innovation as the core means of fulfilling social responsibility.

- $\quad$ Effect. The effect of Innovation Leading focuses on contribution to industry and society.

- Driving. Innovation leading relies more on the innovation culture consciousness of corporate management and employees.

The specific contents are shown in table 2.

\subsection{The process of Innovation Leading (ISAC)}

- User demand is the trigger of innovation Intention, which is the "navigator" and "brain". It is reflected in the cycle of innovation needsinnovation mind-innovation goals and provides value judgment for innovation strategy.

- Innovation Strategy plays a guiding role, is the "command" of Innovation Leading, and is the innovation plan of technology and Complementary Assets under the guidance of Innovation Intention.

- Innovation Action is the carrier of Innovation Leading and the action after the Innovation Strategy has been established, and the key to enhance Core Competence, including technological innovation and complementary asset innovation.

- Core Competence is the goal of Innovation Leading. It is not only a "touchstone" for testing whether the innovation process meets the needs of users, but also feedback to the innovation intention to optimize the innovation process. It is an organic unity of technological competence market competence, organizational competence and cultural competence.

The specific contents are shown in fig. 1

TABLE II. THE CORE VARIABLES OF "INNOVATION LEADING"

\begin{tabular}{|c|c|c|}
\hline \multirow{2}{*}{$\begin{array}{l}\text { Core } \\
\text { variable }\end{array}$} & \multicolumn{2}{|l|}{ Innovation Leading } \\
\hline & Case evidence & $\begin{array}{l}\text { Main } \\
\text { category }\end{array}$ \\
\hline Value & $\begin{array}{l}\text { From the Little Prodigy Washing Machine in } 1995 \text { to the Dual Direct Drive Washing } \\
\text { Machine in } 2018 \text {, its R \& D and design originated from the market demand, all of } \\
\text { which are based on solving the market pain points and satisfying the demands of users. }\end{array}$ & User demands \\
\hline Attitude & $\begin{array}{l}\text { "Nowadays, the demands of users have increased, and clothes of various materials have } \\
\text { appeared, but dry cleaning cannot guarantee cleanliness, which requires a third cleaning } \\
\text { revolution. Air washing machines can do a lot of research based on the temperature, } \\
\text { humidity and wind direction of various materials. They have innovated the washing } \\
\text { machine and made many changes in design and technology. We proposed an air } \\
\text { washing machine. There are also washing machines that do not use washing powder to } \\
\text { reduce pollution. The dual direct-drive washing machine solves the problem of time and } \\
\text { electricity consumption." }\end{array}$ & $\begin{array}{l}\text { The Core } \\
\text { Means of } \\
\text { Fulfilling } \\
\text { Social } \\
\text { Responsibility }\end{array}$ \\
\hline Effect & $\begin{array}{l}\text { In the 1980s, Zhang Ruimin said "foreigners only sell us defective products, why can't } \\
\text { we make them?", which deeply reflected the entrepreneur's national feelings. In July } \\
2018 \text {, the two international standards of "Smart Home System Framework and General } \\
\text { Requirements" and "General Requirements and Interoperability Specifications for IoT" } \\
\text { led by Haier formally passed the review of the Institute of Electrical and Electronics } \\
\text { Engineers (IEEE) and successfully established projects to start leading the industry } \\
\text { trend. }\end{array}$ & $\begin{array}{l}\text { Focus on } \\
\text { contribution } \\
\text { to industry } \\
\text { and society }\end{array}$ \\
\hline Driving & $\begin{array}{l}\text { "In Haier, you are the master and you have to do everything yourself. From research } \\
\text { teams to product innovation, under Integrating Order with Personnel model, we will } \\
\text { spontaneously follow users' needs, gain insight into industry trends and continuously } \\
\text { promote product innovation. Innovation, continuous innovation, is our culture. " }\end{array}$ & culture \\
\hline
\end{tabular}




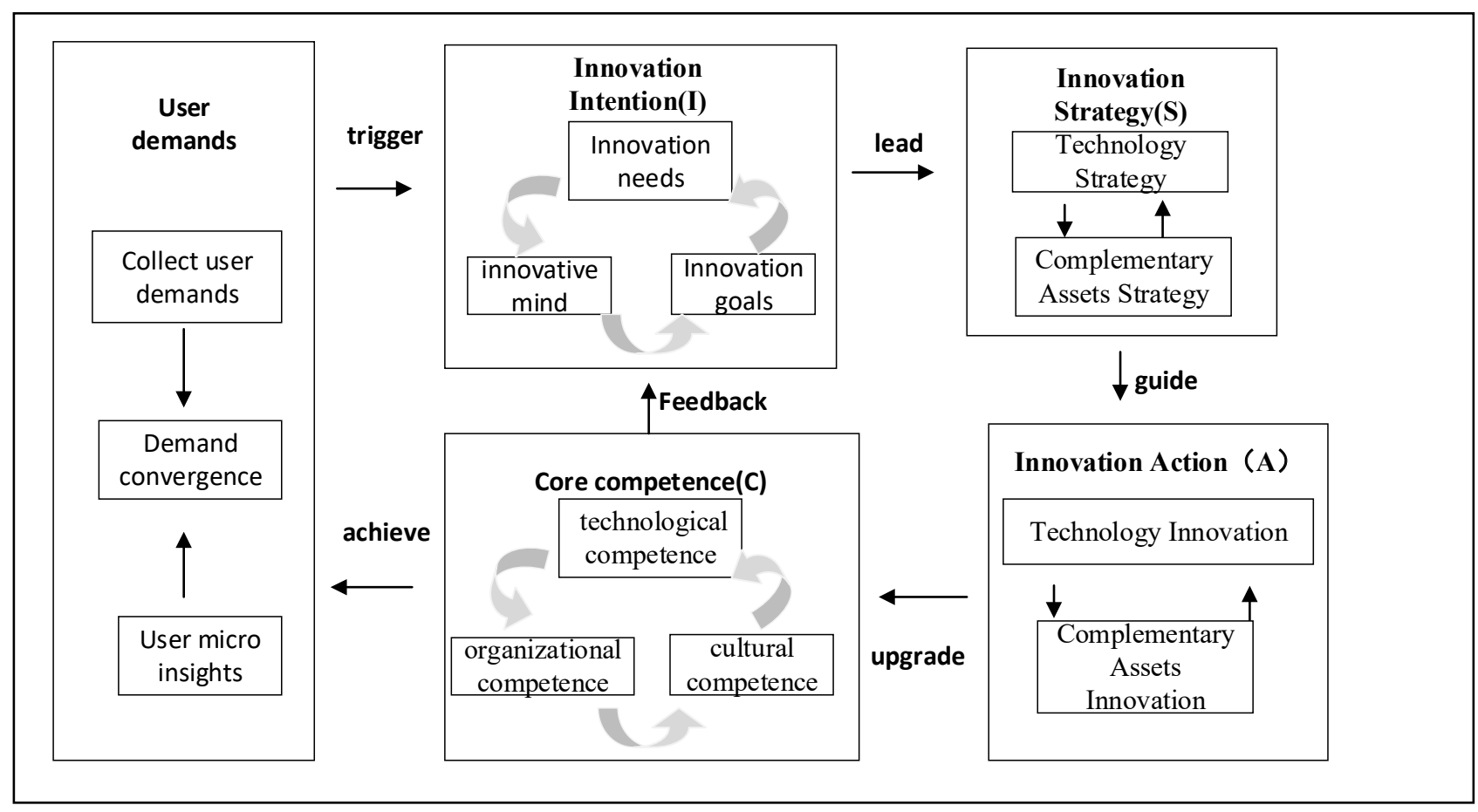

Figure 1. The process of innovation leading(ISAC)

\section{CONCLUSION}

Based on the analysis of innovation practice of Haier Group's washing machine industry line from 1994 to 2019, this paper tentatively defines the concept of Innovation Leading and theoretically discusses the process of Innovation Leading. From four dimensions of Value, Attitude, Effect and Driving (VAED), the concept of Innovation Leading is defined exploratory. This paper theoretically discusses the process of Innovation Leading, namely ISAC model, including Innovation Intention, Innovation Strategy, Innovation Action and Core Competence. It can be clearly seen from this that Innovation Leading is of great importance to the promotion of the core competence. However, at the same time, Haier washing machine industry line has rapidly integrated external and even global research and development resources by using HOPE platform. External resources have played an important role in washing machine product innovation. With the development path from Catching-up to Beyond Catching-up, company relies mainly on resources to improve their innovation Competence and obtain sustainable competitive advantage, which is increasingly weakening. Therefore, late-developing companies in China, represented by Haier Group, must adopt the sustainable development paradigm of Innovation Leading.

\section{Acknowledgment}

Supported by the National Natural Science Foundation of China(715721), The project of the Chinese Academy of Engineering, "Made in China: Research on Innovation Strategies and Governance Structure Beyond Catching Up" (2017-XY-39); Major Project of Chinese Academy of Engineering: "Research on Breakthrough Path of Key Core Technology' Neck-sticking' Problem"; Tianyou Youth Talent Lift Program of Lanzhou Jiaotong University

\section{References}

1. Wang Zhigang. Insisting on Leading Development with Innovation and Accelerating the Construction of an Innovative Country [R]. study times, 2018-0629.

2. Dosi G. Technological Paradigms and Technological Trajectories[J].Research Policy , 1982(11):147 162.

3. Shelby Danks, Jay Rao, Jeff M Allen. Measuring Culture of Innovation: A Validation Study of the Innovation Quotient Instrument(Part 2)[J]. Performance Improvement Quarterly , 2017(1):29 53.

4. Xu Qingrui. Total Innovation Management: Theory and Practice [M]. Beijing: Science Press, 2007.

5. Leifer R, MdDermott C M., O’Connor G C , Peters L S, Rice M P, and Veryzer, R.W. Radical Innovation: How Mature Companies Can Outsmart Upstarts[M].Boston : Harvard Business School Press,2000.

6. Clayton M Christensen, Michael E Raynor. Why Hard-nosed Executives Should Care about 
Management Theory[J].Harvard business review,2003(9):66 74.

7. Hargadon A B. How Breakthroughs Happen: The Surprising Truth about How companies Innovate[M]. Boston: Harvard Business School Press,2003.

8. O'Connor G. Major Innovation as a Dynamic Capability: A Systems Approach [J].Journal of Product Innovation Management, 2008(2):313 330.

9. Eisenhardt K M. Building Theories from Case Study Research[J].Academy of Management Review , 1989(4):532 550. 